\title{
Use of non-lethal endpoints to establish water quality requirements and optima of the endangered Topeka shiner (Notropis topeka)
}

\author{
Rory T. Mott · Amanda E. Rosenberger • \\ Doug Novinger
}

Received: 29 January 2021 / Accepted: 7 September 2021 / Published online: 4 October 2021

(C) The Author(s) 2021

\begin{abstract}
Water quality standards based on sublethal effects and performance optima for aquatic organisms, rather than onset of mortality, are more ecologically relevant for management of species of conservation concern. We investigated the effects of hypoxia, temperature (with acclimation), nitrogenous chemical compounds, and chloride on Topeka shiners (Notropis topeka) by monitoring behavioral responses to a reduction in oxygen and, using swimming speed, determining thermal optima and onset of effect for concentrations of nitrogenous compounds and chloride. We found $\mathrm{ASR}_{50}$ (i.e., dissolved oxygen concentrations where $50 \%$ of fish use aquatic surface respiration) to be $1.65 \mathrm{mg} / \mathrm{L}$ and $\mathrm{ASR}_{90}$ to be $1.08 \mathrm{mg} / \mathrm{L}$ of dissolved oxygen. Optimum temperatures for the species ranged from 17.7 to $28.0^{\circ} \mathrm{C}$, while predicted $100 \%$ mortality ranged from 33.7 to $40.3{ }^{\circ} \mathrm{C}$, depending on the temperature at which fish were acclimated prior to experiments. Ammonia and sodium chloride
\end{abstract}

\section{R. T. Mott ( $\square)$}

Environmental Services Program, Missouri Department of Natural Resources, Jefferson City, MO, USA

e-mail: rorymott1988@gmail.com

A. E. Rosenberger

U.S. Geological Survey, Tennessee Cooperative Fishery Research Unit, Tennessee Tech University, Cookeville, TN, USA

\section{Novinger}

Resource Science Division, Missouri Department of Conservation, Columbia, MO, USA reduced swimming speed at concentrations below known $\mathrm{LC}_{50}$ values, while nitrite concentrations did not correspond with swimming speed, but rather, post-experiment mortality. This provides insight into where Topeka shiners can not only persist, but also thrive. Although swimming speed may not be a suitable metric for determining the effects of all contaminants, our focus on optima and sub-lethal effects over tolerance allows selections of the most suitable reintroduction site matching the species' physiological profile.

Keywords Aquatic ecology - Endangered species · Freshwater · Physiology $\cdot$ Topeka Shiner

\section{Introduction}

Freshwater systems in North America are experiencing a rapid decline in freshwater biodiversity (Richter et al. 1997) due to an assortment of factors, including stream channelization, competition, sedimentation, pollution, and predation by nonnative fishes. Though less visually dramatic than other forms of habitat degradation, poor water quality can devastate the aquatic community and limit the distributions of sensitive species (Meador and Frey 2018). In particular, stable populations of the federally listed endangered Topeka shiner have been linked to locations with favorable water quality conditions (Tabor 1998; Bayless et al. 2003; MDC 2010), though they likely possess a broad 
tolerance to adverse water quality conditions associated with seasonal flow variation. To advance Topeka shiner conservation and recovery, managers will benefit from a better understanding of optimal physiological conditions for the species to evaluate threats to populations and the suitability of reintroduction sites.

Studies used to establish water quality standards are often lethal to the target organism, an approach that is poorly suited for evaluating chronic stress or optimal conditions (Poole et al. 2004). Conditions below lethal threshold values may still impede growth and development, especially when considering the complex nature of compounding, low-level stressors. Further, for some applications such as reintroduction, an understanding of threshold values for mortality may be of less interest than understanding physiological optima, or the levels at which water quality characteristics increase potential fitness of organisms. Longer water quality studies based on growth and reproduction require a substantial time commitment (Mount 1973) and are vulnerable to mechanical failures. Topeka shiner reproduction is complicated and typically requires a host nest (Kerns 1983; Pflieger 1997), which can limit the experimental design of growth and reproductive studies.

Despite its association in Missouri with good water quality (Bayless et al. 2003), the Topeka shiner is likely adapted to overcoming challenging conditions over its life history. Living in isolated pools that seasonally suffer from desiccation and high nutrient load, the species must contend with hypoxia typical of prairie streams (Hatch 2001). A common approach to identify hypoxia tolerance is to observe behavioral response to a gradual reduction in oxygen in a controlled environment (Chapman and Liem 1995); this incorporates potential for both physiological and behavioral adaptations to low oxygen levels. Fish species adapted to hypoxia may exhibit behaviors that compensate for lack of oxygen in the water column, such as aquatic surface respiration (ASR). Aquatic surface respiration is defined as a behavioral mechanism by which the fish ventilates its gills at the thin, oxygenated layer near the water surface (Kramer 1983). Multiple species of fish use ASR to persist under hypoxia; however, this behavior comes at potential costs (Domenici et al. 2007; Chapman and McKenzie 2009). Loss of schooling formation, coupled with vulnerability to aerial attacks, makes ASR risky and reduces time and energy for other important behaviors (e.g., feeding, reproduction); it is therefore likely employed only when other physiological or morphological adaptations for extracting oxygen from the water column fail to maintain fish metabolism (e.g., increased hemoglobin content, larger gill surface area, lowered metabolic rate; Domenici et al., 2007).

Not only hypoxia, but other water quality factors, such as temperature and the presence of chemical stressors, can affect fish fitness through different physiological modes. Metabolic capacity, the ability to uptake oxygen and circulate it throughout the body, is often measured as a surrogate for potential fitness and overall performance (McPhee and Janz 2014). In particular, measures of fish swimming performance are individually repeatable, can demonstrate aerobic capacity, and yield comparable data among individuals, thereby providing a useful reflection of basic physiological function (Farrell et al. 1998; Plaut 2001). Critical swimming speed measures maximum aerobic capacity in fish by incrementally increasing speed until the animal exhibits fatigue; its intent is to determine how fast a fish can swim until its energetic resources are exhausted (Hammer 1995). By using a faster procedure to estimate critical swimming speed, termed ramped critical swimming speed (Jain et al. 1998), we can determine an optimum range of temperatures for Topeka shiner aerobic scope, account for the effects of acclimation, and estimate lethal limits. Thermal performance curves, built with swimming tests, can give insight into how temperature influences fitness-related traits including activity, growth, and metabolic rate (Speers-Roesch and Norin 2016). Furthermore, changes in critical swimming speed of fish provide information on physiological stress that can be directly related to mortality-based tests (i.e., $\mathrm{LC}_{50}$ tests) without harming the fish (Hammer 1995).

In addition to swimming tests, we can measure how acute exposure to different test temperatures can affect feeding rates at particular acclimation temperatures (Meeuwig et al. 2004). Results from thermal optimum swimming tests, predicted lethal limits, feeding optima, and laboratory observations of behavior originating from different experimental acclimations can be combined into one descriptive figure known as a thermal polygon (Fry et al. 1942; Elliott 1995). For fish of conservation concern, this figure can provide managers with thermal zones detailing growth, tolerance, and incipient 
lethal levels, which can be used to evaluate or manage habitat for its potential fitness benefits. In addition to thermal experiments, our swimming tests can also demonstrate what concentrations of low-level chemical stressors will first cause a deviation of swimming speed from expected for standard experimental and acclimation temperatures. The use of impaired swimming speed to examine sub-lethal stress is a wellpracticed method (Cripe et al. 1984; Eissa et al. 2010; McKenzie et al. 2007). Demonstrating what sublethal factors may cause changes in swimming speed that could be detrimental to the fitness of individuals provides more meaningful information on the ability of fish to cope with stressful chemical conditions. Additionally, information on chemical stressors may help identify specific environmental concerns (e.g., high nitrogen loads, road salt) for the Topeka shiner.

Costly conservation efforts may be misguided without a solid understanding of both physical habitat and water quality requirements of a species proposed for reintroduction, such as the Topeka shiner. To provide this information, our goal is to explore how water quality conditions influence the physiology and behavior of $N$. topeka. Using non-lethal physiological tests, we planned to (1) observe $N$. topeka's behavioral responses to a gradual reduction in oxygen, (2) determine thermal optima at different acclimation temperatures as indicated by swimming speed, and (3) pinpoint when the onset of stress occurs for sublethal levels of nitrogenous chemical compounds and chloride concentrations using swimming speed. Our emphasis on non-lethal experimental endpoints has a twofold advantage of preventing unnecessary stress on fish used in the experiments and providing a more ecologically relevant assessment of tolerance. This information will yield insight into where reintroduced Topeka shiners can not only persist, but also thrive; our focus on optima over tolerance allows selection of the most suitable reintroduction sites matching the species' physiological profile.

\section{Methods}

This study was performed under the auspices of the University of Missouri IACUC protocol 8222. Permits were provided by the Missouri Department of Conservation (Permit \#16,547) and the Fish and
Wildlife Service (Permit \# TE74488B-0). On December 11, 2015, the United States Fish and Wildlife Service Neosho National Fish Hatchery provided 432 Topeka shiners (Table 1) from propagated stocks obtained from Sugar Creek in Harrison County, MO (these were the first generation produced from fish obtained from the Lost Valley Fish Hatchery; cultured fish from these locations are intended to be used for reintroduction programs). The fish were acclimated to room temperature over $4 \mathrm{~h}$ and introduced into a 1000-L, aerated holding tank maintained at $23 \pm 1{ }^{\circ} \mathrm{C}$ and a 12 -h day and night cycle. Holding tanks were checked three times a week for conductivity, dissolved oxygen, and nitrogenous compounds associated with fish waste to ensure high and stable water quality. Since the fish were mostly juveniles, we spent several months growing the fish with daily morning feedings to satiation with TetraFin fish flakes as recommended by Neosho National Fish Hatchery. Immediately prior to the experiments, fish were divided into three different size classes (i.e., small, $x<30 \mathrm{~mm}$; medium, $30 \mathrm{~mm} \leq x \geq 40 \mathrm{~mm}$; and large, $40 \mathrm{~mm}<x$ ) to organize sample groups for each experiment to ensure representative lengths of the lab population.

Fish behavioral responses to a gradual decrease in ambient oxygen levels were measured in a specially designed, 150-L tank during our trials with an additional group serving as a behavioral reference. For each trial, fish were divided into sample groups over a range of sizes representative of the current Topeka shiner population in the laboratory $(n=10$ fish per trial; Table 1). Because of their endangered status, we were unable to obtain additional animals from the hatchery over the duration of these experiments to control for changes in body size in our laboratory population; however, we included fish from all three size classes in each experiment (i.e., small, $x<30 \mathrm{~mm}$; medium, $30 \mathrm{~mm} \leq x \geq 40 \mathrm{~mm}$; and large, $40 \mathrm{~mm}<x$ ), to avoid size-related bias as much as possible. As such, growth of our fish over the duration of experimentation did not lead to significant differences among hypoxia trials in mean total length and weight among experiments (i.e., ANOVA: mean total length $F=0.49, P=0.87$; ANOVA: mean weight $F=0.59$, $P=0.80$; Table 1). The sample groups were first held under dissolved oxygen conditions reflecting saturation at ambient temperature and atmospheric pressure 
Table 1 Topeka shiner weights and lengths for experiments

\begin{tabular}{|c|c|c|c|c|c|c|}
\hline Description & Date & Number & $\begin{array}{l}\text { Ave. } \\
\text { length } \\
(\mathrm{mm})\end{array}$ & $\begin{array}{l}\text { Std. Dev. } \\
(\mathrm{mm})\end{array}$ & Ave. weight (g) & Std. Dev. (g) \\
\hline Fish starting size & $2015 / 12 / 16$ & 432 & 31 & 5 & 0.22 & 0.14 \\
\hline \multicolumn{7}{|l|}{ Hypoxia trials } \\
\hline Test 1 & $2016 / 05 / 05$ & 10 & 41 & 5 & 0.60 & 0.35 \\
\hline Test 2 & $2016 / 05 / 23$ & 10 & 43 & 6 & 0.61 & 0.25 \\
\hline Test 3 & $2016 / 06 / 21$ & 10 & 44 & 6 & 0.73 & 0.42 \\
\hline Test 4 & $2016 / 06 / 22$ & 10 & 43 & 8 & 0.77 & 0.55 \\
\hline Test 5 & $2016 / 06 / 24$ & 10 & 46 & 7 & 0.88 & 0.40 \\
\hline Test 6 & 2016/07/05 & 10 & 45 & 7 & 0.81 & 0.44 \\
\hline Test 7 & $2016 / 07 / 07$ & 10 & 45 & 6 & 0.82 & 0.37 \\
\hline Test 8 & $2016 / 07 / 08$ & 10 & 44 & 5 & 0.71 & 0.31 \\
\hline Test 9 & $2016 / 07 / 14$ & 10 & 45 & 6 & 0.74 & 0.43 \\
\hline Test 10 & $2016 / 07 / 15$ & 10 & 44 & 7 & 0.90 & 0.55 \\
\hline Behavioral reference & $2017 / 06 / 21$ & 10 & 51 & 10 & 0.76 & 0.33 \\
\hline \multicolumn{7}{|l|}{ Feeding trials } \\
\hline Test $1\left(22^{\circ} \mathrm{C}\right)$ & $2016 / 9 / 29$ & 10 & 44 & 4 & 0.74 & 0.20 \\
\hline Test $2\left(30^{\circ} \mathrm{C}\right)$ & $2016 / 9 / 30$ & 10 & 45 & 4 & 0.86 & 0.34 \\
\hline Test $3\left(35^{\circ} \mathrm{C}\right)$ & $2016 / 10 / 03$ & 10 & 48 & 6 & 0.92 & 0.45 \\
\hline Test $4\left(38^{\circ} \mathrm{C}\right)$ & $2016 / 10 / 24$ & 10 & 44 & 4 & 0.81 & 0.26 \\
\hline \multicolumn{7}{|l|}{$\mathrm{LC}_{50} \mathrm{NACL}$} \\
\hline $\mathrm{NaCl} 0 \mathrm{mg} / \mathrm{L}$ & $2016 / 11 / 30$ & $10^{\mathrm{a}}$ & 48 & 6 & 0.86 & 0.38 \\
\hline $\mathrm{NaCl} 2000 \mathrm{mg} / \mathrm{L}$ & $2016 / 11 / 30$ & $10^{\mathrm{a}}$ & 48 & 6 & 0.89 & 0.40 \\
\hline $\mathrm{NaCl} 3000 \mathrm{mg} / \mathrm{L}$ & $2016 / 11 / 30$ & $10^{\mathrm{a}}$ & 44 & 4 & 0.61 & 0.15 \\
\hline $\mathrm{NaCl} 4000 \mathrm{mg} / \mathrm{L}$ & $2016 / 11 / 30$ & $10^{\mathrm{a}}$ & 47 & 5 & 0.87 & 0.42 \\
\hline $\mathrm{NaCl} 6000 \mathrm{mg} / \mathrm{L}$ & $2016 / 11 / 30$ & $10^{\mathrm{a}}$ & 47 & 6 & 0.84 & 0.44 \\
\hline $\mathrm{NaCl} 8000 \mathrm{mg} / \mathrm{L}$ & $2016 / 11 / 30$ & $10^{\mathrm{a}}$ & 46 & 7 & 0.81 & 0.45 \\
\hline $\mathrm{NaCl} 10,000 \mathrm{mg} / \mathrm{L}$ & $2016 / 11 / 30$ & $10^{\mathrm{a}}$ & 46 & 4 & 0.74 & 0.27 \\
\hline $\mathrm{NaCl} 12,000 \mathrm{mg} / \mathrm{L}$ & $2016 / 11 / 30$ & $10^{\mathrm{a}}$ & 47 & 4 & 0.74 & 0.28 \\
\hline $\mathrm{NaCl} 14,000 \mathrm{mg} / \mathrm{L}$ & $2016 / 11 / 30$ & $10^{\mathrm{a}}$ & 50 & 5 & 1.00 & 0.33 \\
\hline \multicolumn{7}{|l|}{ Thermal trials } \\
\hline Acclimation $10^{\circ} \mathrm{C}$, test $5^{\circ} \mathrm{C}$ & 2016/03/01-2016/06/22 & 10 & 42 & 6 & 0.68 & 0.34 \\
\hline Acclimation $10^{\circ} \mathrm{C}$, test $10^{\circ} \mathrm{C}$ & 2016/03/02-2016/06/21 & 10 & 42 & 4 & 0.66 & 0.23 \\
\hline Acclimation $10^{\circ} \mathrm{C}$, test $17^{\circ} \mathrm{C}$ & 2016/02/05-2016/06/16 & 10 & 39 & 3 & 0.47 & 0.12 \\
\hline Acclimation $10^{\circ} \mathrm{C}$, test $23^{\circ} \mathrm{C}$ & 2016/02/09-2016/06/06 & 10 & 39 & 4 & 0.48 & 0.19 \\
\hline Acclimation $10^{\circ} \mathrm{C}$, test $30^{\circ} \mathrm{C}$ & 2016/02/11-2016/06/03 & 10 & 39 & 3 & 0.48 & 0.16 \\
\hline Acclimation $23{ }^{\circ} \mathrm{C}$, test $10^{\circ} \mathrm{C}$ & 2016/03/04-2016/05/23 & 10 & 40 & 5 & 0.52 & 0.19 \\
\hline Acclimation $23^{\circ} \mathrm{C}$, test $17^{\circ} \mathrm{C}$ & 2016/02/01-2016/05/27 & 10 & 37 & 3 & 0.38 & 0.11 \\
\hline Acclimation $23{ }^{\circ} \mathrm{C}$, test $23^{\circ} \mathrm{C}$ & 2016/01/28-2016/05/17 & 10 & 42 & 6 & 0.60 & 0.26 \\
\hline Acclimation $23{ }^{\circ} \mathrm{C}$, test $30^{\circ} \mathrm{C}$ & 2016/03/28-2016/05/19 & 10 & 38 & 5 & 0.38 & 0.19 \\
\hline Acclimation $23{ }^{\circ} \mathrm{C}$, test $35^{\circ} \mathrm{C}$ & $2016 / 02 / 23-2016 / 05 / 23$ & 10 & 40 & 4 & 0.56 & 0.15 \\
\hline Acclimation $30^{\circ} \mathrm{C}$, test $10^{\circ} \mathrm{C}$ & 2016/03/03-2016/06/14 & 10 & 39 & 4 & 0.48 & 0.16 \\
\hline Acclimation $30^{\circ} \mathrm{C}$, test $17^{\circ} \mathrm{C}$ & 2016/02/02-2016/06/16 & 10 & 39 & 3 & 0.50 & 0.16 \\
\hline Acclimation $30^{\circ} \mathrm{C}$, test $23^{\circ} \mathrm{C}$ & 2016/01/25-2016/06/08 & 10 & 39 & 3 & 0.47 & 0.11 \\
\hline Acclimation $30^{\circ} \mathrm{C}$, test $30^{\circ} \mathrm{C}$ & $2016 / 02 / 15-2016 / 06 / 10$ & 10 & 42 & 3 & 0.55 & 0.15 \\
\hline Acclimation $30^{\circ} \mathrm{C}$, test $35^{\circ} \mathrm{C}$ & 2016/02/18-2016/06/13 & 10 & 40 & 4 & 0.54 & 0.17 \\
\hline
\end{tabular}


Table 1 (continued)

\begin{tabular}{|c|c|c|c|c|c|c|}
\hline Description & Date & Number & $\begin{array}{l}\text { Ave. } \\
\text { length } \\
(\mathrm{mm})\end{array}$ & $\begin{array}{l}\text { Std. Dev. } \\
(\mathrm{mm})\end{array}$ & Ave. weight (g) & Std. Dev. (g) \\
\hline \multicolumn{7}{|l|}{ Chemical trials } \\
\hline $\mathrm{NaCl} 5000$ ppm & 2016/07/06-2016/07/12 & 10 & 43 & 6 & 0.75 & 0.39 \\
\hline $\mathrm{NaCl} 2500$ ppm & 2016/07/12-2016/07/15 & 10 & 43 & 8 & 0.76 & 0.44 \\
\hline $\mathrm{NaCl} 1250$ ppm & 2016/07/15-2016/07/25 & 10 & 55 & 4 & 0.67 & 0.21 \\
\hline $\mathrm{NaCl} 625$ ppm & 2016/07/25-2016/08/05 & 10 & 46 & 6 & 0.86 & 0.45 \\
\hline $\mathrm{NaCl} 315$ ppm & 2016/08/01-2016/08/05 & 10 & 47 & 6 & 0.85 & 0.36 \\
\hline $\mathrm{NaNO}_{3} 20 \mathrm{mg} / \mathrm{L}$ & 2016/09/30-2016/09/06 & 10 & 44 & 8 & 0.84 & 0.62 \\
\hline $\mathrm{NaNO}_{3} 15 \mathrm{mg} / \mathrm{L}$ & 2016/10/07-2016/11/03 & 10 & 47 & 5 & 0.90 & 0.28 \\
\hline $\mathrm{NaNO}_{3} 10 \mathrm{mg} / \mathrm{L}$ & 2016/10/13-2016/11/3 & 10 & 48 & 8 & 1.00 & 0.48 \\
\hline $\mathrm{NaNO}_{3} 5 \mathrm{mg} / \mathrm{L}$ & 2016/10/24-2016/10/31 & 10 & 46 & 5 & 0.88 & 0.33 \\
\hline $\mathrm{NH}_{3} 50 \mathrm{mg} / \mathrm{L}$ & 2017/01/30-2017/02/03 & $10^{\mathrm{b}}$ & 46 & 6 & 0.75 & 0.27 \\
\hline $\mathrm{NH}_{3} 25 \mathrm{mg} / \mathrm{L}$ & 2017/02/06-2017/02/22 & $10^{\mathrm{b}}$ & 45 & 4 & 0.60 & 0.11 \\
\hline $\mathrm{NH}_{3} 15 \mathrm{mg} / \mathrm{L}$ & 2017/02/22-2017/03/01 & $10^{\mathrm{b}}$ & 47 & 4 & 0.71 & 0.23 \\
\hline $\mathrm{NH}_{3} 10 \mathrm{mg} / \mathrm{L}$ & 2017/03/02-2017/03/17 & $10^{\mathrm{b}}$ & 48 & 6 & 0.73 & 0.40 \\
\hline $\mathrm{NH}_{3} 5 \mathrm{mg} / \mathrm{L}$ & 2017/03/17-2017/03/29 & $10^{b}$ & 47 & 7 & 0.75 & 0.38 \\
\hline
\end{tabular}

${ }^{a}$ Topeka shiners reused from thermal $\mathrm{U}_{\text {crit }}$ trials for $\mathrm{NaCl} \mathrm{LC}_{50}$ after 5 months of rest

${ }^{\mathrm{b}}$ Topeka shiners reused from hypoxia trials for $\mathrm{NH}_{3}$ swimming tests after 6 months of rest

$(>8 \mathrm{mg} / \mathrm{L})$ in $37-\mathrm{L}$ aquaria to prevent acclimation to hypoxia. After introduction to the test tank, a 30-min behavioral acclimation allowed fish to adjust to the new environment. Four bubblers, two located at each end of the tank, were set behind plastic mesh screens to minimize disturbance to the experimental animals while a submersible pump circulated the water. At initiation of each trial, nitrogen gas was introduced through the bubblers to displace oxygen in the water from $>8.0$ to $<0.20 \mathrm{mg} / \mathrm{L}$ over the timeframe of approximately $2 \mathrm{~h}$. When nitrogen was no longer effective in reducing oxygen levels in the water, 8- to $10 \mathrm{-g}$ portions of sodium sulfite were added directly into the tank above the bubblers to create extreme hypoxia (i.e., > $1.0 \mathrm{mg} / \mathrm{L}$ dissolve oxygen) (Kramer 1983; Chapman et al. 1995). A YSI EcoSense ODO 200 probe, located in the center of the tank, continuously monitored oxygen levels (i.e., with precision at $\pm 1.5 \%$ of reading or $\pm 0.15 \mathrm{mg} / \mathrm{L}$; whichever is greater). Topeka shiner's behavior and oxygen concentration were concurrently monitored and recorded during experimentation using two video cameras hidden behind a blind. Each trial was concluded $15 \mathrm{~min}$ after concentrations reached $<0.20 \mathrm{mg} / \mathrm{L}$ of dissolved oxygen.
A two-camera system (i.e., GoPro Hero 4 cameras) was used to track fish position in the tank over the duration of the trial and later analyzed using VidSync, software for measuring individual fish coordinates in three dimensions (Neuswanger et al. 2016). Data were collected at predetermined oxygen concentrations from video footage: water oxygen content in milligrams per liter, percent of fish using ASR, 3-D coordinates of fish within the tank, and loss of equilibrium or death of individual fish. In addition, observations of any unusual behaviors such as jumping and aggression were noted in the video footage.

The primary goal of the swim tube protocol was to determine the ramped critical swimming speed (ramped $U_{\text {crit }}$ ) of individual fish. With the swimming tube, it was important to standardize and/or control for the following: (1) holding stress (e.g., short-term acclimation to experimental conditions); (2) flow characteristics (e.g., uniform, steady flow); (3) metabolic state of the fish (e.g., empty stomach, long-term acclimation or holding temperatures); (4) temperature; (5) and water quality (e.g., normoxia). To ensure all fish were in a similar metabolic state, individuals were fasted a minimum of $48 \mathrm{~h}$ prior to testing in the swim tunnel (Matthews and Maness 1979). We use 
the following terms to describe fish acclimation to experimental conditions: (1) long-term acclimation, which refers to conditions, particularly temperature, at which fish were held for at least 2 weeks prior to the experiment; (2) short-term acclimation, which refers to a holding period $<12 \mathrm{~h}$ long for fish to adjust to experimental temperatures; and (3) behavioral acclimation, a 30-min holding period in the experimental conditions for fish to adjust to the new environment and recover from handling stress. The $<12-\mathrm{h}$ short-term acclimation was implemented to minimize physiological stress related to rapid changes in temperature while avoiding initiation of full physiological acclimation to the experimental temperature treatment. The short-term acclimation to the swimming tube is expected to imitate daily temperature fluctuations and should not change long-term physiological acclimation (Podrabsky and Somero 2004).

After introduction to the swim tunnel, electric barriers were activated and held at low voltage (6-8 V) (Ward et al. 2002), and the fish were given an additional 30-min behavioral acclimation in the tube with no flow. Following this, we used the standardized ramped $U_{\text {crit }}$ protocol developed by Jain et al. (1998), in which the initial increases in water velocity occur at 5-min intervals until they approach maximum swimming speed, after which water velocity is ramped at 20-min intervals until termination of the experiment. Water velocity was increased by $3 \mathrm{~cm} / \mathrm{s}$ every $5 \mathrm{~min}$ until velocity was at $75 \%$ of the estimated $U_{\text {crit }}$ value obtained from pilot runs with red shiners and data from previous work (Adams et al. 2000); then, velocity in the swimming tube was increased by $3 \mathrm{~cm} / \mathrm{s}$ every $20 \mathrm{~min}$. The incremental increase in swimming speed, or "step size," was based on the average body size of Topeka shiners in the laboratory population (i.e., study population average of Topeka shiner body size $3.1 \mathrm{~cm}$, SD $0.5 \mathrm{~cm}$; Table 1). For the ramped $U_{\text {crit }}$ test, it was important to ensure that at least two 20-min intervals were completed to accurately determine a ramped $U_{\text {crit }}$ value (Jain et al. 1998). The trial ended when a fish was fatigued and unable to leave the rear electrical barrier after $10 \mathrm{~s}$.

Temperature tolerances and optima were measured using ramped $U_{\text {crit }}$ as an indication of metabolic capacity. Sample groups of fish from each size class ( $n=10$ fish for 15 trials, for a total of 150 fish) were subdivided into three different holding temperatures for a 2-week acclimation period based on previous temperature experiments on specific growth of Topeka shiners (Adams et al. 2000; Koehle and Adelman 2007). Similarly, a 2-week longterm acclimation period for experiments involving CTM (critical thermal maximum, or the temperature at which fish lose equilibrium when exposed to an acute ramped temperature protocol $-1^{\circ}$ every $3 \mathrm{~min}$ ) measurements was used on red shiners (Matthews and Maness 1979). Each sample group was comprised of fish representative of the lab population such that the range and average size of individuals varied as little as possible among treatments (Table 1). Swimming speed was calculated based on fish total length (i.e., fish lengths/s) to account for minor differences among sample groups due to growth and small laboratory population size. Five groups were acclimated to $10{ }^{\circ} \mathrm{C}$ in an Environmental Growth Chamber (i.e., model number W2WH-150-TAC-001), while a second Environmental Growth Chamber (i.e., model number W2WH-150-TAC-001) acclimated five additional groups to $30{ }^{\circ} \mathrm{C}$. Another five groups were held and acclimated to ambient temperature $\left(23^{\circ} \mathrm{C}\right)$ over a 2-week period. For each long-term acclimation temperature, fish were tested for ramped $U_{\text {crit }}$ at $5,10,17,23,30$, and $35 \pm 1{ }^{\circ} \mathrm{C}$ experimental temperatures, except in cases where temperature differences between long-term acclimation temperatures and experimental temperatures were too extreme for fish to survive short-term acclimation, even when extended $12 \mathrm{~h}$. Water temperature in the swimming tube was adjusted with an AquaEuroUSA Model: MC-1/4HD chiller or with a $2500 \mathrm{~W}$ Process Technology Immersion Heater. Sample groups from thermal experiments underwent long-term acclimation and were tested concurrently; sequential experiments were staggered by acclimation temperature through time to avoid the confounding effects of growth with experimental or acclimation temperatures. This process was repeated until all fish were tested.

We further explored thermal, sub-lethal endpoints by performing a feeding limit test on Topeka shiners acclimated to room temperature $\left(23 \pm 1{ }^{\circ} \mathrm{C}\right)$ for a 2 -week period. Groups of $n=10$ were created by randomly selecting fish from each size group $(n=10$ per trial; 23, 30, 35, and $38 \pm 1{ }^{\circ} \mathrm{C}$; ANOVA: mean total length among treatments $F=0.55, P=0.18$; mean weight among treatments $F=0.54, P=0.65$, Table 1) and were placed in a $150-\mathrm{L}$ tank for a 2 -h acclimation period. The ambient temperature was slowly raised to 
the test temperature (i.e., $23,30,35$, and $38 \pm 1{ }^{\circ} \mathrm{C}$ ) using $2500 \mathrm{~W}$ Process Technology Immersion Heater while a small, submersible pump circulated the water for uniform heating. For $n=10$ fish for each trial, fish were fed $0.2 \mathrm{~g}$ of TetraMin fish flakes in the experimental tank. The ration was chosen based on daily observations from feeding $n=10$ fish at room temperature. Topeka shiner feeding strikes were recorded over a 5-min period for all fish. Trials were video recorded for later review to count the number of feeding attempts for each test temperature. Data were then summarized to indicate at what temperature feeding attempts significantly decreased or ceased altogether.

Using ramped $U_{\text {crit }}$ as an indication of metabolic capacity and fitness, we examined how the Topeka shiner responded to select chemical concentrations below lethal levels. In addition to exploring sub-lethal effects, we determined traditional, acute lethal tolerance to chloride, ammonia, and nitrite by researching literature and, when information was not available, conducting $\mathrm{LC}_{50}$ experiments. We found $\mathrm{LC}_{50}$ values for ammonia and nitrite from previous experiments (Adelman et al. 2009), but no information on Topeka shiner chloride tolerances. Therefore, we tested lethal concentrations for chloride before estimating sublethal effects. For this mortality-based experiment, Topeka shiners were acclimated to room temperature $\left(23 \pm 1{ }^{\circ} \mathrm{C}\right)$ for 2 weeks and placed in 37-L aquaria set at nine chloride concentrations (i.e., 0, 2000, 3000, $4000,6000,8000,10,000,12,000$, and 14,000 mg/L $\mathrm{NaCl}$ ) with other factors held constant. Because of our limited number of specimens, we reused fish from thermal swimming tests for our $\mathrm{LC}_{50}$ test. Fish were given approximately 5 months of rest (Table 1) after thermal swimming tests before sorting into experimental tanks in a manner to avoid confounding fish lengths with experimental temperature $(n=10$; ANOVA: mean total length $P=0.47, F=0.97$, ANOVA: mean weight $P=0.48, F=0.96$; Table 1) based on the average size of the Topeka shiner lab population. Fisher BioReagent reagent-grade sodium chloride was used for $\mathrm{LC}_{50}$ trials. After the groups were introduced into each treatment to initiate the trial, the number of dead fish was assessed at regular time intervals by experimental chloride concentration (e.g., 0, 2, 4, 6, 8, 12, 24, 36, 48, 72, and 96 h).

For chemical swimming tests, conductivity and $\mathrm{pH}$ were controlled in the swimming tube with a combination of $7.5 \mathrm{pH}$ buffer (MicroLife $7.5 \mathrm{pH}$ Buffer), deionized water, and dechlorinated tap water. For our treatment chemicals used to dose the swimming tube, we used solid reagent-grade ammonium chloride (Sycamore Life Sciences RDCA0430-500B1), sodium nitrite (Sigma 52,252), and sodium chloride (Fisher BioReagents BP-358-10). We reached target test concentrations by continuously monitoring chemical levels with a Hydrolab DS4x Multiparameter Data Sonde as the dissolved solution was slowly added from a 1-L beaker. If water chemistry changed during or between tests, we would add small amounts of deionized water or dissolved chemical to adjust concentrations and swim tube water was completely replaced after each $n=10$ chemical trial. Fish were sorted into 15 groups ( $n=10$; 5 groups for each chemical trial), again avoiding confounding length with experimental conditions (Table 1). Due to a low number of available specimens, Topeka shiners from earlier hypoxia trials were sorted and reused in ammonia swimming experiments after approximately 6 months of rest (Table 1). The first chemical treatment used for ramped $U_{\text {crit }}$ starting treatment was set at $\mathrm{LC}_{25}$ for chloride, ammonia, and nitrite. Based on the swimming response of the fish, the remaining treatment concentrations were determined, with the focus on finding the lowest concentrations that corresponded with significantly decreased swimming speed. Experiments were conducted consecutively due to the finite supply of chemicals and deionized water. As described above, final swimming speed results were standardized by total fish length to account for small differences among experimental fish in size. Deviation from maximum potential swimming speed at the same acclimation temperatures $\left(23 \pm 1{ }^{\circ} \mathrm{C}\right)$ indicated the concentration of the chemical corresponding to the onset of metabolic stress.

To evaluate response to hypoxic conditions, we measured the percentage of fish in each of the ten trials using ASR at set oxygen concentrations (e.g., 8.00, 7.00, 6.00, 5.50, 5.00, 4.50, 4.00, 3.75, 3.50, $3.25,3.00,2.75,2.50,2.25,2.00,1.75,1.50,1.25$, $1.00,0.75,0.50$, and $0.25 \mathrm{mg} / \mathrm{L} \mathrm{O}_{2}$ ). We then created a binomial linear model in R software program (Venables and Ripley 2002; R Core Team 2015) by categorizing all fish from each trial into two groups based on use or non-use of ASR at each oxygen concentration. Next, we calculated $\mathrm{ASR}_{90}$ and $\mathrm{ASR}_{50}$ from the binomial model as a measure of hypoxia tolerance (Chapman et al. 1995). We determined goodness 


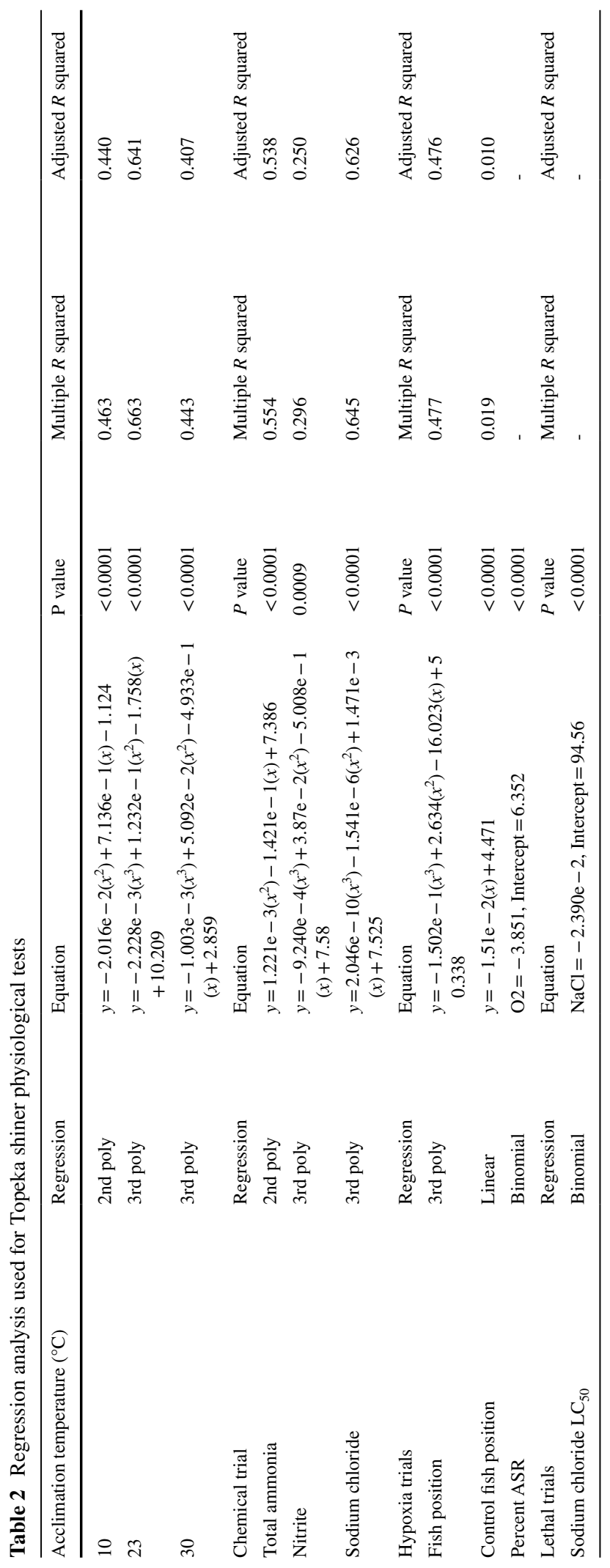


Fig. 1 Binomial curve summarizing the response of Topeka shiner to a gradual reduction in oxygen over the course of $n=10$ trials with each point representing the percentage of Topeka shiner using aquatic surface respiration (ASR) for all trials

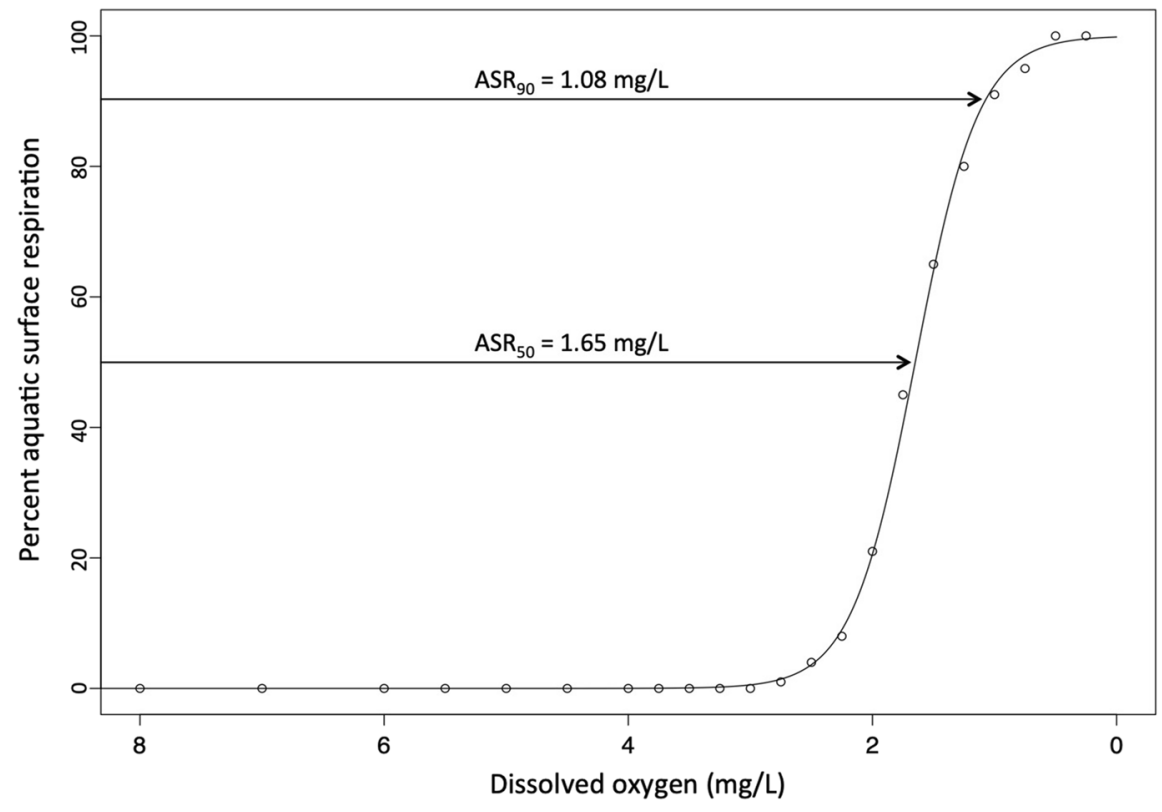

of fit for the binomial model using the Hosmer and Lemeshow test (Lele et al. 2014). For our position analysis, we used Vidsync, software that triangulates fish position from a two-camera perspective, to calculate three-dimensional coordinates of fish in our test tank (Neuswanger et al. 2016). For each of our selected oxygen concentrations, we used Vidsync to determine coordinates of fish from all 10 hypoxia trials and the normoxia behavioral reference test. We then fit a polynomial regression model to the position data and used $95 \%$ confidence intervals to calculate oxygen values corresponding to when fish initiated a change in aquarium position (Wickham 2009; R Core Team 2015). Equal variance was tested with Bartlett's test. The final trial served as a behavioral reference to confirm that ASR percentages and vertical fish positions remain constant under normoxia (i.e., $>8 \mathrm{mg} / \mathrm{L}$ dissolved $\mathrm{O}_{2}$ ).

From our combined thermal swimming speed trials, we constructed a thermal performance curve (best-fit polynomial model using $R^{2}$ and adjusted $R^{2}$ values; Condon et al. 2010; Table 2) for each acclimation temperature using $\mathrm{R}$ statistical package (Wickham 2009; R Core Team 2015). The peaks of the
Table 3 Effects table of physiological optima and tolerances for the Topeka shiner
${ }^{a}$ Value obtained fromAdelman et al. (2009)

\begin{tabular}{|c|c|c|c|c|}
\hline \multicolumn{5}{|l|}{ Swimming trials } \\
\hline $\begin{array}{l}\text { Acclimation tem- } \\
\text { perature }\left({ }^{\circ} \mathrm{C}\right)\end{array}$ & $P$ value & Predicted optimum $\left({ }^{\circ} \mathrm{C}\right)$ & \multicolumn{2}{|l|}{$\begin{array}{l}\text { Predicted } 100 \% \\
\text { mortality }\left({ }^{\circ} \mathrm{C}\right)\end{array}$} \\
\hline 10 & $<0.0001$ & 17.7 & \multicolumn{2}{|l|}{33.7} \\
\hline 23 & $<0.0001$ & 25.7 & \multicolumn{2}{|l|}{37.5} \\
\hline 30 & $<0.0001$ & 28.0 & \multicolumn{2}{|l|}{40.3} \\
\hline Chemical & $P$ value & $\mathrm{LC}_{50}$ & \multicolumn{2}{|l|}{ Effect detected } \\
\hline Total ammonia & $<0.0001$ & $21.4 \mathrm{mg} / \mathrm{L}^{\mathrm{a}}$ & \multicolumn{2}{|l|}{$7.6 \mathrm{mg} / \mathrm{L}$} \\
\hline Nitrite & 0.0009 & $6.1 \mathrm{mg} / \mathrm{L}^{\mathrm{a}}$ & \multicolumn{2}{|l|}{$4.7 \mathrm{mg} / \mathrm{L}$} \\
\hline Sodium chloride & $<0.0001$ & $3942 \operatorname{ppm}(P<0.0001)$ & \multicolumn{2}{|l|}{1993 ppm } \\
\hline \multicolumn{5}{|l|}{ Behavioral trials } \\
\hline Hypoxia & $P$ value & Effect detected & $\mathrm{ASR}_{50}$ & $\mathrm{ASR}_{90}$ \\
\hline Fish position & $<0.0001$ & $5.52 \mathrm{mg} / \mathrm{L}$ & - & - \\
\hline Percent ASR & $<0.0001$ & - & $1.65 \mathrm{mg} / \mathrm{L}$ & $1.08 \mathrm{mg} / \mathrm{L}$ \\
\hline
\end{tabular}




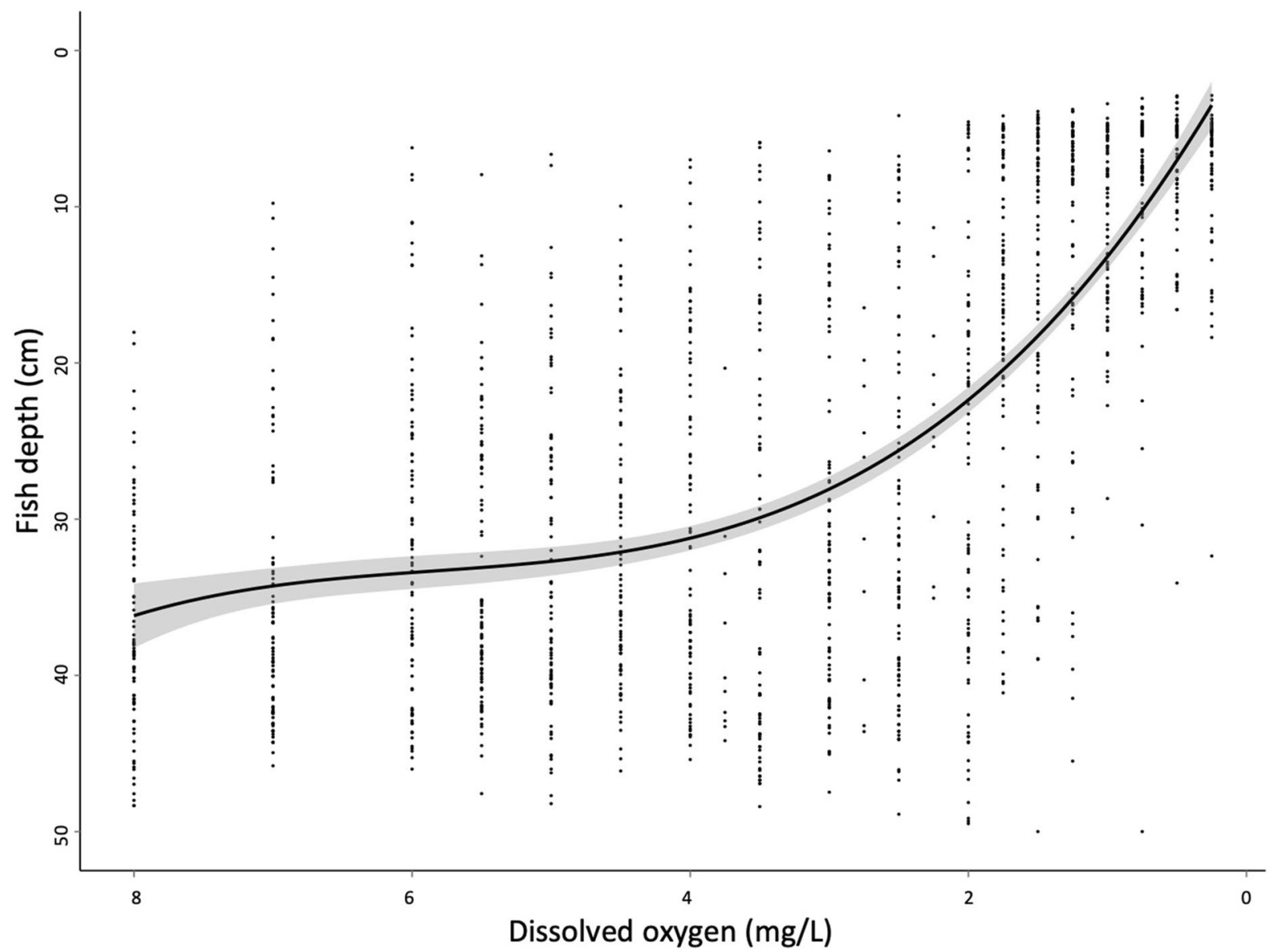

Fig. 2 Polynomial regression of the average depth of Topeka shiner in experimental tanks over a range of oxygen concentration with a $95 \%$ confidence interval around the line with

curves represented the temperatures at which maximum growth under full rations would be expected. After the regression equations were computed, we calculated the temperature that had the highest predicted maximum swimming speed. Through extrapolating the regression lines to higher test temperatures, we also predicted what temperatures would result in $100 \%$ mortality for each acclimation temperature. We then performed Bartlett's test on our treatments to test for equal variances. Feeding trials were visually assessed for indication of pattern in number of attempts at food across the four experimental temperatures.

For the $\mathrm{NaCl} \mathrm{LC}_{50}$ test, we used $\mathrm{R}$ software program to calculate the $\mathrm{LC}_{50}$ value (Venables and Ripley 2002; R Core Team 2015). To determine goodness of fit, a $P$ value was calculated for the binomial each point representing individual observations in position for $n=100$ individuals for $n=10$ trials at selected oxygen concentrations

distribution using the Hosmer and Lemeshow test (Lele et al. 2014). For all chemical swimming trials, we calculated best-fit polynomial regression lines in $\mathrm{R}$ software program with $95 \%$ confidence intervals (Wickham 2009; R Core Team 2015; Table 2). We found when the chemical concentration first corresponded with a significant decrease in swimming speed by comparing $95 \%$ confidence intervals along the mean to the $95 \%$ confidence around 0 concentration. Bartlett's test was used to test for equal variances.

\section{Results}

During the hypoxia tolerance experiments, Topeka shiners initiated ASR at $2.75 \mathrm{mg} / \mathrm{L} \mathrm{O}_{2}$ (32\% oxygen 
Fig. 3 Polynomial regressions of ramped critical swimming speed (ramped $\left.U_{\text {crit }}\right)$, standardized by body length of Topeka shiners acclimated to (a.) $10^{\circ} \mathrm{C}$, (b.) $23{ }^{\circ} \mathrm{C}$, and (c.) $30{ }^{\circ} \mathrm{C}$ and tested over a ranged of experimental conditions with the shaded zone representing the $95 \%$ confidence intervals around the lines
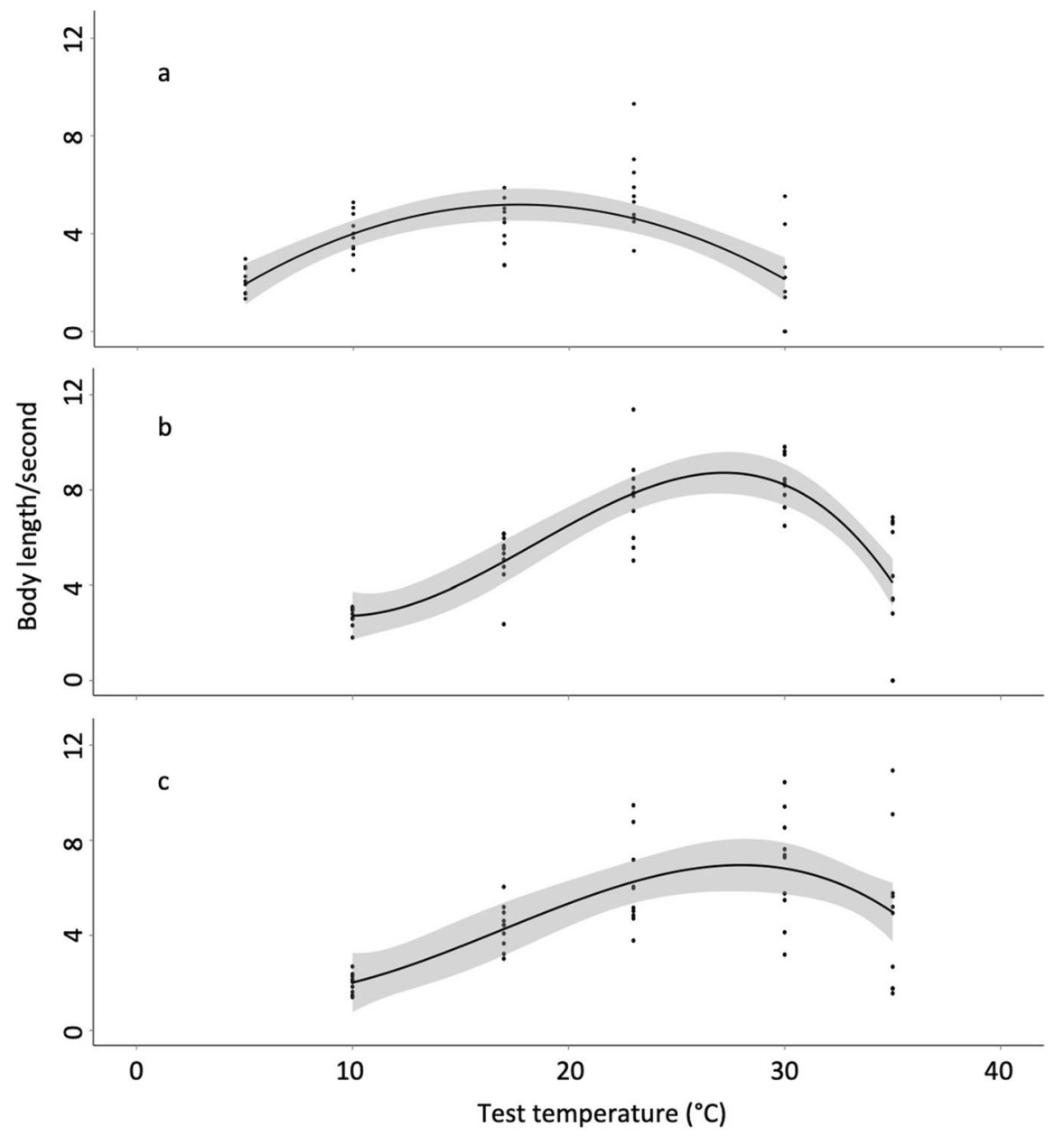

available for freshwater at $23{ }^{\circ} \mathrm{C}$ ), and, at $0.50 \mathrm{mg} / \mathrm{L}$ $\mathrm{O}_{2}(6 \%)$, all fish were using ASR, with $\mathrm{ASR}_{50}$ measured at $1.65 \mathrm{mg} / \mathrm{L} \mathrm{O}_{2}(19 \%)$ and $\mathrm{ASR}_{90}$ measured at $1.08 \mathrm{mg} / \mathrm{L} \mathrm{O}_{2}$ (12\%) (Fig. 1; Table 3). At $5.52 \mathrm{mg} / \mathrm{L}$ $\mathrm{O}_{2}(63 \%)$, fish initiated a rise to the water surface, and variation in water position visibly decreased (Bartlett's test $K^{2}=3520, P<0.001$; Fig. 2). Loss of equilibrium and deaths $(n=21)$ occurred at concentrations $\leq 0.45 \mathrm{mg} / \mathrm{L}(5 \%)$ with 19 mortalities occurring at concentrations below $0.25 \mathrm{mg} / \mathrm{L} \mathrm{(3 \% ).} \mathrm{A} \mathrm{one-way}$ ANOVA test indicated that Topeka shiners that lost equilibrium or died were significantly larger in weight $(F=24.7, \quad P<0.001)$ and total length $(F=15.5$, $P<0.001)$ than individuals surviving the hypoxia trials. No aggression, buccal bubble holding, synchronized schooling, or flight attempts were observed during the tests.
Fish acclimated to $10{ }^{\circ} \mathrm{C}$ had a predicted maximum ramped critical swimming speed of 5.2 body lengths/s at $17.7{ }^{\circ} \mathrm{C}$ with a predicted mortality of $100 \%$ at $33.7^{\circ} \mathrm{C}$ (Fig. 3). Variance among individual trials was the greatest at the highest test temperatures, which were considerably greater than the acclimation temperature (Bartlett's test $K^{2}=85.9, P<0.001$ ). Fish acclimated to $23{ }^{\circ} \mathrm{C}$ had the highest predicted maximum swimming speed of 8.6 body lengths/s at $25.7^{\circ} \mathrm{C}$ and a predicted mortality of $100 \%$ at $37.5^{\circ} \mathrm{C}$ (Fig. 3), showing similar patterns in among-individual variance between test temperatures (Bartlett's test $\left.K^{2}=59.6, P<0.001\right)$. Finally, Topeka shiners acclimated to $30{ }^{\circ} \mathrm{C}$ had a predicted maximum swimming speed of 6.7 body lengths/s at $28.0{ }^{\circ} \mathrm{C}$ and the highest predicted temperature for $100 \%$ mortality at $40.2{ }^{\circ} \mathrm{C}$ (Fig. 3), again with an increase in variance among individuals at the highest test temperatures 
Fig. 4 Ramped critical swimming speed (ramped $U_{\text {crit }}$ ) of Topeka shiners exposed to a range of ammonia (a), nitrite (b), and sodium chloride (c) concentrations with polynomial regressions shown and $95 \%$ confidence intervals around the lines
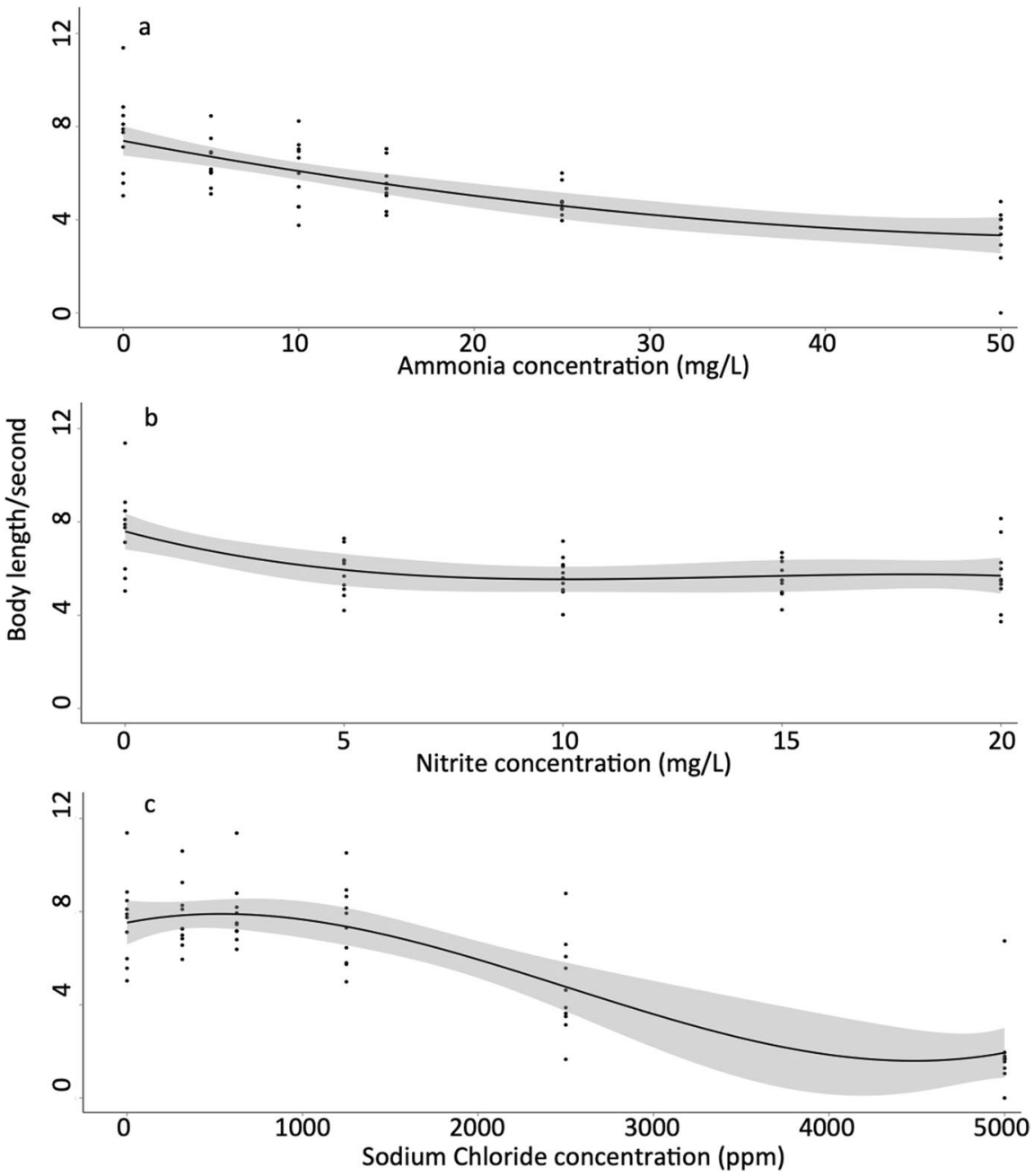

(Bartlett's test $\left.K^{2}=62.5, P<0.001\right)$. Two mortalities were observed at acclimation of $10{ }^{\circ} \mathrm{C}$ at $30{ }^{\circ} \mathrm{C}$ test temperature and at acclimation of $23{ }^{\circ} \mathrm{C}$ at test temperature of $35^{\circ} \mathrm{C}$. Based on our swimming speed tests, Topeka shiners demonstrated maximum metabolic activity between 17.7 and $28.0{ }^{\circ} \mathrm{C}$, depending on acclimation, with a lethal limit of $33.7^{\circ} \mathrm{C}$ to $40.3{ }^{\circ} \mathrm{C}$ (Table 3; Fig. 3). In general, Topeka shiners showed signs of stress at test temperatures above their acclimation temperature, including behaviors such as excessive gill ventilation, venturing into electrical barriers, and searching the top of the swimming tube for an escape.

In our feeding tests, we demonstrate how feeding strikes over time can differ with experimental temperature. Fish acclimated to $23{ }^{\circ} \mathrm{C}$ exhibited the most feeding attempts over a 5-min period at the
$30{ }^{\circ} \mathrm{C}$ test temperature. The final trial at the highest test temperatures (i.e., $38{ }^{\circ} \mathrm{C}$ ) resulted in a dramatic reduction in the number of feeding attempts, accompanied by $100 \%$ mortality immediately following test conclusion.

Swimming speed deviated from what was expected at 0 concentration at $7.6 \mathrm{mg} / \mathrm{L}$ total ammonia with one mortality occurring at $10 \mathrm{mg} / \mathrm{L}$ and three occurring at $50 \mathrm{mg} / \mathrm{L}$ (Fig. 4). Variance in swimming speed increased with increased concentration of ammonia (Bartlett's test $K^{2}=179, P<0.001$ ). Nitrite did not reduce swimming speed beyond an initial drop from 0 concentration conditions (Fig. 4). Regardless of experimental nitrite concentrations, fish exhibited similar swimming speeds; however, 7 mortalities were observed at $15 \mathrm{mg} / \mathrm{L}$ and 8 at $20 \mathrm{mg} / \mathrm{L}$. Although Bartlett's test revealed differences in 
variance among samples, variance did not increase with chemical concentration $\left(K^{2}=93.5, P<0.001\right)$. For sodium chloride, for which no tolerance values were available in the literature for Topeka shiner, we experimentally determined the $\mathrm{LC}_{50}$ value to be $3942 \mathrm{ppm}$ to inform swimming tests. To account for possible bias of fish reuse from earlier thermal swimming speed experimentations, we rested fish for approximately 5 months before conducting our $\mathrm{LC}_{50}$ test (Table 1). Swimming speeds were comparable in our first four treatments and first decreased significantly from expected (speed at $0 \mathrm{ppm}$ ) at a concentration of 1993 ppm sodium chloride (Fig. 4; Table 3). As with ammonia, variance among groups increased with the concentration of sodium chloride (Bartlett's test $\left.K^{2}=673, \mathrm{p}<0.001\right)$. Prior experimentation with hypoxia may have caused bias in the ammonia swimming experiments; however, we attempted to control for previous stressors by allowing a rest period of approximately 6 months (Table 1 ).

\section{Discussion}

We anticipated, for our study, that Topeka shiners would display broad water quality tolerances for naturally occurring stressors typical of the prairie environment in which they evolved (Smale and Rabeni 1995). However, because Topeka shiners are slated for reintroduction into new habitats with the goal of recovery, acute tolerance was of secondary interest than information on water quality characteristics that allow individuals to thrive. Our focus on water quality optima and the sub-lethal impacts of stressors allows selection of the most suitable watersheds for reintroduction and leads to a greater understanding of the Topeka shiner's physiological profile. Our findings, however, are based on propagated and laboratory-reared fish. We may expect wild populations to demonstrate greater hardiness and tolerances due to greater genetic diversity (Overturf et al. 2003), ongoing selection for harsh conditions (Timmerman and Chapman 2004), or ontogenetic exposure to harsh conditions (Gamperl and Farrell 2004). However, because fish from these stocks are intended for reintroduction programs, our findings may be relevant to management for this species' recovery, if not necessarily reflective of the species as a whole.
For our experiments, Topeka shiners demonstrated anticipated tolerance to hypoxic water quality conditions, comparable to other species of Notropis (Gee et al. 1978; Smale and Rabeni 1995; Ostrand and Wilde 2001). This corroborates past research showing that Topeka shiners can tolerate periods of hypoxia, though with considerable reductions in growth rate and increased vulnerability to predation (Domenici et al. 2007; Koehle and Adelman 2007). While Topeka shiners can persist through periods of acute hypoxia, chronic hypoxia may prove more problematic. We found that, at intermediate levels of oxygen $(5.52 \mathrm{mg} / \mathrm{L}(63 \%$ maximum saturation of oxygen for freshwater at $23{ }^{\circ} \mathrm{C}$ )), Topeka shiners significantly altered their position closer to the water surface, where they may be more vulnerable to aerial predation (Domenici et al. 2007). In past studies, growth of Topeka shiners slowed when held at dissolved oxygen concentrations below $4 \mathrm{mg} / \mathrm{L}$ (Koehle and Adelman 2007). In our hypoxia trials, we found that larger Topeka shiners were more likely to lose equilibrium or die during hypoxia experiments, presumably due to higher metabolic demands that could not be met via obtaining oxygen at the air-water interface (Small et al. 2014). This may be of some concern for larger adult Topeka shiners that have reached sexual maturity encountering acute hypoxia. Our mortalities and losses of equilibrium occurred at dissolved oxygen levels $\leq 0.45 \mathrm{mg} / \mathrm{L}$, below a measured 96-h $\mathrm{LC}_{50}$ of $1.26 \mathrm{mg} / \mathrm{L}$ of dissolved oxygen (Koehle and Adelman 2007). Current standards set by the Missouri Department of Natural Resources (MDNR) require warm-water fisheries to have a minimum of $5 \mathrm{mg} / \mathrm{L}$ of dissolved oxygen (MDNR 2014). This standard might not be completely protective, as we observed behavioral impacts occurring at $5.52 \mathrm{mg} / \mathrm{L}$, supporting stricter dissolved oxygen criteria if negative behaviors, as well as mortality impacts, are to be avoided. If reintroduction sites chronically fall below these levels, or result in prolonged periods of ASR for Topeka shiner or other suboptimal behaviors, it could jeopardize reintroduction attempts by lowering individual fitness, even if hypoxia does not directly lead to individual mortality.

In addition to hypoxic conditions, prairie environments bring extreme fluctuations in stream temperature, forcing fish to either find thermal refugia or persist via thermal tolerance (Mundahl 1990). Our predicted index of upper thermal tolerance for Topeka 
Fig. 5 Topeka shiner thermal tolerance polygon showing the zones of growth based on ramped critical swimming speed tests (ramped $U_{\text {crit }}$ ) and feeding tests at $23{ }^{\circ} \mathrm{C}$ with solid lines constructed from thermal experiments and dashed lines hypothesized using laboratory observations during acclimation

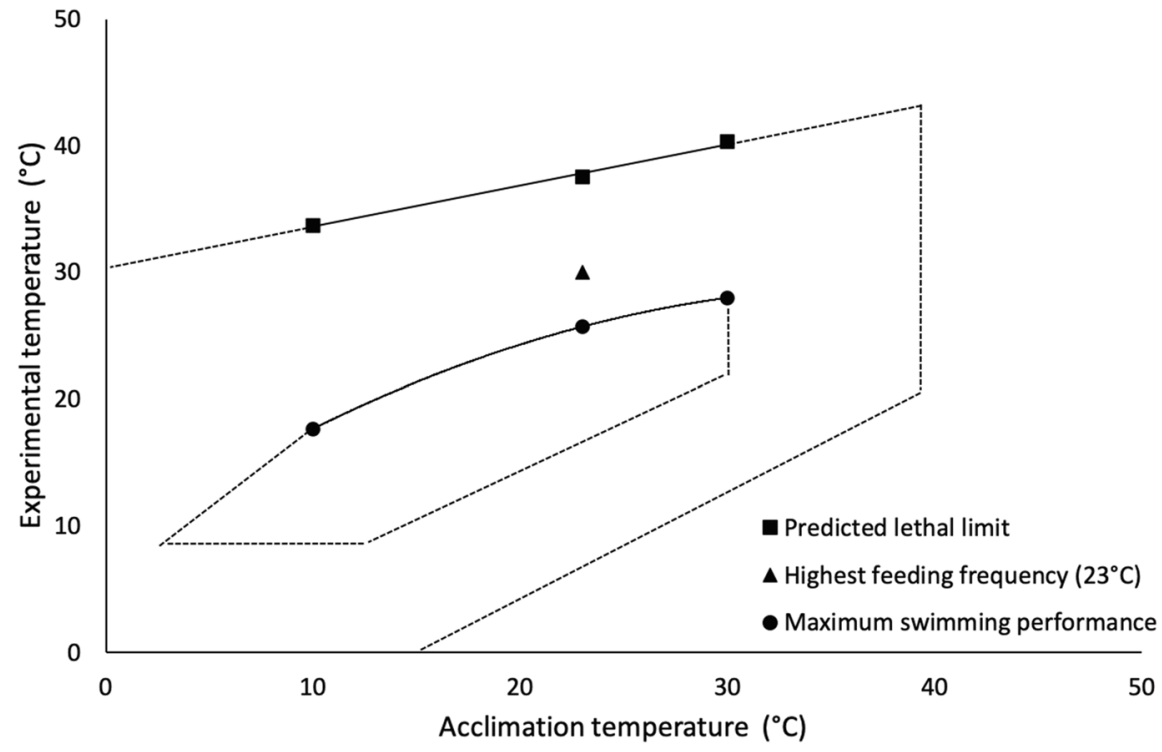

shiners was 33.7 to $40.3{ }^{\circ} \mathrm{C}$, depending on their longterm acclimation temperatures (i.e., test temperatures $\left.10,23,30 \pm 1{ }^{\circ} \mathrm{C}\right)$. Similar results were found in past studies when Topeka shiners measured a critical thermal maximum (CTM) of $39{ }^{\circ} \mathrm{C}$ at a $31{ }^{\circ} \mathrm{C}$ acclimation (Koehle and Adelman 2007). Many minnow species demonstrate high CTM, with the red shiner and plains minnow having similar measures of CTM to the Topeka shiner (Matthews and Maness 1979; Smale and Rabeni 1995; Ostrand and Wilde 2001). In addition to tolerance, fish thermal performance curves are important to explore because of the correspondence with optimum temperature for activity, growth, and metabolic rate (Kellogg and Gift 1983; SpeersRoesch and Norin 2016). In our ramped critical swimming speed tests, Topeka shiner predicted maximum metabolic activity for our 10,23 , and $30 \pm 1{ }^{\circ} \mathrm{C}$ acclimation temperatures measured 17.7, 25.7, and $28.0^{\circ} \mathrm{C}$, respectively. This closely matches previous findings, indicating Topeka shiner maximum growth rate (i.e., \% growth per day) occurs when acclimated to approximately $27^{\circ} \mathrm{C}$ (Koehle and Adelman 2007).

To visually describe our findings on Topeka shiner thermal physiology, we combined our thermal data, predicted values, feeding test results, and observations from acclimation into three zones describing growth, feeding, and mortality based on the fish acclimation and ambient temperature (Fig. 5), though some components of the figure (i.e., dashed lines), particularly thresholds at lower temperatures, remain hypotheses.
The lethal zone is defined as any ambient temperature that lies above the predicted incipient lethal levels from the swimming test (Fig. 5). Our incipient lethal level curve closely matched results that showed Topeka shiner CTM of $39{ }^{\circ} \mathrm{C}$ when acclimated to $31{ }^{\circ} \mathrm{C}$ (Koehle and Adelman 2007). The region that defines fish stress is located above the maximum ramped critical swimming speed performance and below the predicted lethal level. Greatest growth and reproduction of Topeka shiners are expected to occur in the optimum zone below maximum swimming performance. This zone represents not only temperatures that result in the highest metabolic potential of the species, but also the adaptive potential of the Topeka shiner to adjust to different ambient temperatures based on acclimation. The triangle point at $30{ }^{\circ} \mathrm{C}$ indicates the test temperature with the highest feeding frequency for $23{ }^{\circ} \mathrm{C}$ acclimated Topeka shiners (Fig. 5). Complete mortality from the $38{ }^{\circ} \mathrm{C}$ feeding test closely matched our predicted incipient lethal limit of $37.5{ }^{\circ} \mathrm{C}$ from ramped $U_{\text {crit }}$ tests with Topeka shiners acclimated to the same temperature (i.e., $23^{\circ} \mathrm{C}$ ). More feeding tests performed at different acclimation temperatures can further define a region of reduced growth. Overall, our results indicate the adaptability of Topeka shiners to changes in acclimation and experimental temperatures.

High salt concentrations, which can occur naturally in inland systems, particularly in closed watersheds (Kelly et al. 2008), can also increase artificially 
as a result of road or agricultural runoff (Corsi et al. 2010) and influence abundance of less tolerant species (Ostrand and Wilde 2001). Deviation of the maximum swimming speed from standard conditions yielded information on the negative consequences of excessive concentrations of nitrogenous chemical compounds that may be introduced into streams from animal waste, application of chemical fertilizers, or other anthropogenic sources. Naturally occurring chemical stressors in stream environments can exacerbate already stressful conditions such as hypoxia or high temperatures. These compounds concentrate during periods of drought when prairie stream habitats may be reduced to isolated pools (Ostrand and Wilde 2001), or increase during runoff events from numerous non-point sources (Carpenter et al. 1998).

Our acute swimming speed experiments with ammonia revealed a gradual reduction in swimming speed with increased concentration, as expected. At $7.6 \mathrm{mg} / \mathrm{L}$ total ammonia, ramped critical swimming speed first significantly deviated from 0 concentration tests, a value considerably below the known $\mathrm{LC}_{50}$ value of $21.4 \mathrm{mg} / \mathrm{L}$ for adult Topeka shiners (Adelman et al. 2009). Current Missouri water quality standards set by the MDNR (2014) have acute total ammonia for cool and warm fisheries restricted below $19.9 \mathrm{mg} \mathrm{N} / \mathrm{L}$ (assuming $\mathrm{pH}=7.5$ ), while chronic conditions are restricted to $2.6 \mathrm{mg} \mathrm{N} / \mathrm{L}$ (assuming $\mathrm{pH}=7.5$ ). Our results indicate that acute increases in ammonia concentration measuring below current standards can have substantial sub-lethal effects on Topeka shiners. In addition, experiments predicting Topeka shiner embryo-juvenile maximum acceptable toxicant concentration demonstrate vulnerability to low total ammonia concentrations (Adelman et al. 2009). Current standards for acute and chronic ammonia concentrations might therefore be inadequate to designate or protect suitable areas for Topeka Shiner reintroduction.

Unlike ammonia, increased concentrations of nitrite did not consistently reduce swimming speed at concentrations above $10 \mathrm{mg} / \mathrm{L}$. Instead, concentrations of 15 and $20 \mathrm{mg} / \mathrm{L}$ were associated with mortality after termination of the experiments. We concluded that our swimming speed tests did not adequately measure the immediate metabolic effect of nitrite on Topeka shiners. For future studies on nitrite, longer sustained swimming speed, more detailed critical swimming speed treatments above $10 \mathrm{mg} / \mathrm{L}$, or traditional measures of tolerance would be more appropriate for this particular stressor. The manifestation of gill irritation and other soft tissue damage from nitrite may take longer to elicit an effect than a 2-h swimming test allows. Nitrite uptake causes methemoglobin (hemoglobin that cannot unbind to oxygen) to form in the blood, from which we would anticipate an eventual, if not immediate, reduction in oxygen-carrying capacity in the blood (Lewis and Morris 1986). The constant conversion of methemoglobin back to hemoglobin can take 24 to $48 \mathrm{~h}$ (Lewis and Morris 1986). Post-experimental mortalities indicate that, after gradually absorbing nitrite during swimming tests, fish may have been unable to absorb oxygen for post-experiment recovery. We conclude that ramped critical swimming speed is not a useful metric for measuring the effect of toxic stressors when the onset of stress or the physiological pathway of removal or compensation is delayed. A longer, sustained swimming test or an examination of growth under chronic exposure may be better suited to capture the onset of stress at sub-lethal levels of nitrite concentrations.

In our ramped critical swimming speed tests, Topeka shiners decreased in swimming speed with an increased concentration of chloride, deviating significantly at concentrations considerably less than our estimated lethal concentrations (1993 ppm versus $3942 \mathrm{ppm}$ ). A similar onset of effect was observed with the fathead minnow $\left(\mathrm{IC}_{25}\right.$, i.e., the concentration at $25 \%$ inhibition $=1810 \mathrm{ppm}$; Corsi et al. 2010), although the fathead minnow has a higher $\mathrm{LC}_{50}$ tolerance of 7650 ppm (Adelman et al. 1976). Headwater streams in Missouri that are home to the Topeka shiner can achieve $100 \mathrm{mg} / \mathrm{L}$ of dissolved chloride ion (Bayless et al. 2003). As it follows, standards in Missouri for acute chloride toxicity are $988 \mathrm{mg} / \mathrm{L}$ and are $610 \mathrm{mg} / \mathrm{L}$ for chronic toxicity, assuming a hardness of $400 \mathrm{mg} / \mathrm{L}$ (MDNR 2014). Streams can experience an artificial increase in chloride levels from chronic road salt runoff that is detrimental to community structure, diversity, and productivity (Corsi et al. 2010). These concentrations can often be exceeded in urban environments or heavy-traffic roads with substantial runoff (Gardner and Royer 2010). Chronic, persistent chloride concentrations may be of concern to the Topeka shiner and can be addressed in future studies.

State and Federal agencies are invested in recovery plans to manage the federally endangered Topeka 
shiner (Shearer et al. 2003; Mammoliti 2004; MDC 2010). Specifically, the Missouri Department of Conservation is investigating several watersheds for suitability for reintroduction of the Topeka shiner into its former range (MDC 2010). Successful implementation of these plans may benefit from an understanding of mechanistic linkages between species' physiology and environmental conditions (Foin et al. 1998). Differences among watersheds in water quality characteristics are likely to be subtle, and existing information based on extermination that relies on mortality endpoints is too coarse to differentiate what locations have optimum water quality conditions for reintroduced populations of Topeka shiner. Water quality information provided in this study can provide more stringent, data-based criteria for aiding managers in identifying which sites have water quality characteristics most likely to maximize individual fitness. In addition to physical characteristics of the sites, this information can be integrated into a decision framework for prioritization of reintroduction sites that not only ensure survival, but also maximize potential growth and reproduction of stocked individuals. Finally, information on water quality optima provided herein could inform ongoing efforts to predict the species' current and future distribution (Wall et al. 2004).

Water quality optima and tolerances of the Topeka shiner can be used in conjunction with information on other species in the system to promote recovery and persistence. Topeka shiners are nest associates of the orangespotted sunfish (Lepomis humilis) and the green sunfish (Lepomis cyanellus) (Kerns 1983; Pflieger 1997). These fish are remarkably tolerant of hypoxic conditions when compared to other common headwater stream fish (Smale and Rabeni 1995). In addition, the orangespotted sunfish and green sunfish have similar maximum thermal levels when compared to the Topeka shiner (Smale and Rabeni 1995). This suggests that habitat that temporarily experiences hypoxic conditions and high temperatures could still support not only the Topeka shiner but also its nest associates. Alternatively, the relatively high tolerance of the Topeka shiner could provide opportunities for managers to reduce harm from its predators or competitors whose range of water quality tolerances may not be as great by selecting reintroduction sites that are temporarily stressful. Populations of largemouth bass (Micropterus salmoides) originating in small stream impoundments are a known threat to the species (Hatch 2001), pushing Topeka shiners into less favorable habitat for foraging and reproduction (Knight and Gido 2005). These areas, though less favorable from a water quality standpoint, may serve as important refugia from a relatively intolerant predatory species (e.g., Chapman et al. 1995, 1996). The largemouth bass is considerably less tolerant to hypoxia and hyperthermia than the Topeka shiner and its nest associates (Smale and Rabeni 1995). Although low oxygen conditions can negatively affect Topeka shiner behavior and growth (Koehle and Adelman 2007), it can also prevent exotic invasions of largemouth bass into headwater streams while still permitting the shiner and its nest associates to persist.

The methodology presented in this study reflects our desire to understand water quality conditions promoting survival and maximizing growth and reproduction of the Topeka shiner. While our hypoxia tests followed a standard methodology, our novel use of the software, Vidsync, to analyze position and behavior is a relatively new approach (Neuswanger et al. 2016). By carefully tracking fish position to a gradual decrease in dissolved oxygen, we can quantify behavioral reactions such as movement toward the surface before the initiation of ASR. This methodology enables a detailed exploration of the initiation of stress and behavioral changes associated with hypoxia. While we tracked fish position in our experiments, the video apparatus coupled with the analytical prowess of Vidsync yielded greater information on the behavioral changes occurring with the gradual oxygen reduction of a hypoxia test and, for some species, may be able to capture additional individual data more accurately (e.g., gill ventilation rate, heart rate, schooling formations).

The use of swimming speed to measure physiological potential of fish is a common practice (Hammer 1995; Plaut 2001). This non-lethal approach for determining optima can yield more ecologically relevant data compared to tolerance studies relying on mortality as an experimental endpoint (i.e., $\mathrm{LC}_{50}$ experiments) (Plaut 2001). Ramped critical swimming speed methodology was successful for testing effect concentrations in our case, with the exception of nitrite. For nitrate, which we did not test in this study, the amount required to elicit a likely physiological response was impractical to obtain in our 40-gallon swimming apparatus. Despite these limitations, our 
non-lethal methodology may be useful for other species of conservation concern. Physiological profiles can be created with relatively low numbers of specimens that would otherwise be impossible with lethal studies. However, swimming experiment methodology may require alteration for those species whose morphology and behavior discourages mid-water swimming (e.g., benthic fishes; Baltz et al. 1982).

Our experiments show, that for some stressors, physiological performance (i.e., active potential for growth and reproduction) is negatively influenced at concentrations far below threshold values obtained through traditional methods. Overall, information on sub-lethal optima yields a more complete and potentially more useful understanding of a species' ecology than traditional tolerance criteria emphasizing lethal and acute effects. Additionally, information of this kind supports management that incorporates the temporal and spatial nature of water quality regimes that drive species distributions in headwater streams (Poole et al. 2004). Regime-based standards, dynamic standards based on the seasonal changes in discharge, coupled with sub-lethal physiological data, could facilitate successful species recovery and environmental protection of our streams, and, ultimately, provide more protection for species like the Topeka shiner.

Acknowledgements We give a special thanks to C. Paukert, C. Wikle, and L. Chapman for their assistance with this study and comments on earlier versions of this manuscript. We also wish to thank our laboratory managers, D. Fox and R. Martin, as well as our technicians and volunteers, V. Burnett, J. Guinnip, R. High, K. Kopp, and B. Para. The Neosho National Fish Hatchery (USFWS) supplied Topeka shiner specimens.

Author contribution Rory Mott-acquisition and analysis of data, conception and design, drafting and revising the paper.

Amanda E. Rosenberger-acquisition of funding, conception and design, drafting and revising the paper.

Doug Novinger-providing management context, drafting and revising the paper.

Funding Funding to this project was provided by the Missouri Department of Conservation.

Data availability All data will be made available upon request.

Code availability $\quad \mathrm{R}$ and VidSynce were used to analyze data. All code and software will be made available upon request.

\section{Declarations}

Ethics approval This study was performed under the auspices of the University of Missouri IACUC protocol \#8222. Permits to carry out the work were provided by the Missouri Department of Conservation (Permit \#16547) and the Fish and Wildlife Service (Permit \# TE74488B-0).

\section{Consent to participate NA}

\section{Consent for publication NA}

Conflict of interest Any use of trade, firm, or product names is for descriptive purposes only and does not imply endorsement by the U.S. Government.

Open Access This article is licensed under a Creative Commons Attribution 4.0 International License, which permits use, sharing, adaptation, distribution and reproduction in any medium or format, as long as you give appropriate credit to the original author(s) and the source, provide a link to the Creative Commons licence, and indicate if changes were made. The images or other third party material in this article are included in the article's Creative Commons licence, unless indicated otherwise in a credit line to the material. If material is not included in the article's Creative Commons licence and your intended use is not permitted by statutory regulation or exceeds the permitted use, you will need to obtain permission directly from the copyright holder. To view a copy of this licence, visit http://creativecommons.org/licenses/by/4.0/.

\section{References}

Adams SR, Hoover JJ, Killgore JK (2000) Swimming performance of the Topeka shiner (Notropis topeka) an endangered Midwestern minnow. Am Midl Nat 144(1):178186. https://doi.org/10.1674/0003-0031(2000)144[0178: SPOTTS]2.0.CO;2

Adelman IR, Kusilek LI, Koehle J, Hess J (2009) Acute and chronic toxicity of ammonia, nitrite, and nitrate to the endangered Topeka shiner (Notropis topeka) and fathead minnows (Pimephales promelas). Environ Toxicol Chem 28(10):2216-2223. https://doi.org/10.1897/08-619.1

Adelman IR, Smith LL Jr, Siesennop GD (1976) Acute toxicity of sodium chloride, pentachlorophenol, Guthion ${ }$, and hexavalent chromium to fathead minnows (Pimephales promelas) and goldfish (Carassius auratus). J Fish Res Board Can 33(2):203-208. https://doi.org/10.1139/ f76-030

Baltz DM, Moyle PB, Knight NJ (1982) Competitive interactions between benthic stream fishes, riffle sculpin, Cottus gulosus, and speckled dace, Rhinichthys osculus. Can J Fish Aquat Sci 39(11):1502-1511. https://doi.org/10. 1139/f82-202

Bayless MA, McManus MG, Fairchild JF (2003) Geomorphic, water quality and fish community patterns associated with the distribution of Notropis topeka in a central Missouri 
watershed. Am Midl Nat 150(1):58-72. https://doi.org/10. 1674/0003-0031(2003)150[0058:GWQAFC]2.0.CO;2

Carpenter SR, Caraco NF, Correll DL, Howarth RW, Sharpley AN, Smith VH (1998) Nonpoint pollution of surface waters with phosphorus and nitrogen. Eco Appl 8(3):559568. https://doi.org/10.1890/1051-0761(1998)008[0559: NPOSWW]2.0.CO;2

Chapman LJ, Chapman CA, Richard OO, Chandler M, Kaufman L, Keiter AE (1996) Refugia for endangered fishes from an introduced predator in Lake Nabugabo, Uganda. Conserv Biol 10(2):554-561. https://doi.org/10.1046/j. 1523-1739.1996.10020554.x

Chapman LJ, Kaufman LS, Chapman CA, McKenzie FE (1995) Hypoxia tolerance in twelve species of East African cichlids: potential for low oxygen refugia in Lake Victoria. Conserv Biol 9(5):1274-1288. https://doi.org/10. 1046/j.1523-1739.1995.9051262.x-i1

Chapman LJ, Liem KF (1995) Papyrus swamps and the respiratory ecology of Barbus neumayeri. In: Luczkovich JJ, Motta PJ, Norton SF, Liem KF (ed) Ecomorphology of fishes. Developments in environmental biology of fishes (vol. 16). Springer, Dordrecht, pp 183-197. https://doi.org/ 10.1007/978-94-017-1356-6_13

Chapman LJ, Mckenzie DJ (2009) Behavioral responses and ecological consequences. In: Richards JG, Farrell AP, Brauner CJ (ed) Fish Physiology (vol. 27). Academic press, pp 25-77. https://doi.org/10.1016/S1546-5098(08) 00002-2

Condon CH, Chenoweth SF, Wilson RS (2010) Zebrafish take their cue from temperature but not photoperiod for the seasonal plasticity of thermal performance. J Exp Biol 213(21):3705-3709. https://doi.org/10.1242/jeb.046979

Corsi SR, Graczyk DJ, Geis SW, Booth NL, Richards KD (2010) A fresh look at road salt: aquatic toxicity and water-quality impacts on local, regional, and national scales. Environ Sci Technol 44(19):7376-7382. https:// doi.org/10.1021/es101333u

Cripe GM, Goodman LR, Hansen DJ (1984) Effect of chronic exposure to EPN and to guthion on the critical swimming speed and brain acetylcholinesterase activity of Cyprinodon variegatus. Aquat Toxicol 5(3):255-266. https://doi. org/10.1016/0166-445X(84)90024-9

Domenici P, Lefrancois C, Shingles A (2007) Hypoxia and the antipredator behaviours of fishes. Philo Trans R Soc London, Ser B 362(1487):2105-2121. https://doi.org/10.1098/ rstb.2007.2103

Eissa BL, Ossana NA, Ferrari L, Salibián A (2010) Quantitative behavioral parameters as toxicity biomarkers: fish responses to waterborne cadmium. Arch Environ Contam Toxicol 58:1032-1039. https://doi.org/10.1007/ s00244-009-9434-4

Elliott JA (1995) A comparison of thermal polygons for British freshwater teleosts. Freshw Forum 5:178-184

Farrell AP, Gamperl AK, Birtwell IK (1998) Prolonged swimming, recovery and repeat swimming performance of mature sockeye salmon Oncorhynchus nerka exposed to moderate hypoxia and pentachlorophenol. J Exp Biol 201(14):21832189. https://doi.org/10.1242/jeb.201.14.2183

Foin TC, Riley SPD, Pawley AL, Ayres DR, Carlsen TM, Hodum PJ, Switzer PV (1998) Improving recovery planning for threatened and endangered species. Bioscience 48(3):177-184. https://doi.org/10.2307/1313263

Fry FEJ, Brett JR, Clawson GH (1942) Lethal limits of temperature for young goldfish. Rev Can Biol 1:50-56

Gamperl AK, Farrell AP (2004) Cardiac plasticity in fishes: environmental influences and intraspecific differences. J Exp Biol 207(15):2539-2550. https://doi.org/10.1242/jeb. 01057

Gardner KM, Royer TV (2010) Effect of road salt application on seasonal chloride concentrations and toxicity in southcentral Indiana streams. J Environ Qual 39(3):1036-1042. https://doi.org/10.2134/jeq2009.0402

Gee JH, Tallman RF, Smart HJ (1978) Reactions of some Great Plains fishes to progressive hypoxia. Can J Zool 56(9):1962-1966. https://doi.org/10.1139/z78-263

Hammer C (1995) Fatigue and exercise tests with fish. Comp Biochem Physiol A 112(1):1-20. https://doi.org/10.1016/ 0300-9629(95)00060-K

Hatch JT (2001) What we know about Minnesota's first endangered fish species: the Topeka shiner. J Minn Acad Sci 65(1):39-46

Jain KE, Birtwell IK, Farrell AP (1998) Repeat swimming performance of mature sockeye salmon following a brief recovery period: a proposed measure of fish health and water quality. Can J Zool 76(8):1488-1496. https://doi. org/10.1139/z98-079

Kellogg RJ, Gift JJ (1983) Relationship between optimum temperatures for growth and preferred temperatures for the young of four fish species. Trans Am Fish Soc 112(3):424-430. https://doi.org/10.1577/15488659(1983)112\%3c424:RBOTFG\%3e2.0.CO;2

Kelly VR, Lovett GM, Weathers KC, Findlay SEG, Strayer DL, Burns DJ, Likens GE (2008) Long-term sodium chloride retention in a rural watershed: legacy effects of road salt on streamwater concentration. Environ Sci Technol 42(2):410-415. https://doi.org/10.1021/es0713911

Kerns HA (1983) Aspects of the life history of the Topeka shiner, Notropis topeka. Kansas. MS Thesis, University of Kansas.

Knight GL, Gido KB (2005) Habitat use and susceptibility to predation of four prairie stream fishes: implications for conservation of the endangered Topeka shiner. Copeia 1:38-47. https://doi.org/10.1643/CE-04-226R1

Koehle JJ, Adelman RA (2007) The effects of temperature, dissolved oxygen, and Asian tapeworm infection on growth and survival of the Topeka shiner. Trans Am Fish Soc 136(6):1607-1613. https://doi.org/10.1577/T07-033.1

Kramer DL (1983) Aquatic surface respiration in the fishes of Panama: distribution in relation to risk of hypoxia. Environ Biol Fishes 8:49-54. https://doi.org/10.1007/BF000 04945

Lele SR, Keim JL, Solymos P (2014) Package "Resource Selection" Resource Selection (Probability) Functions for Use-availability Data.

Lewis WM Jr, Morris DP (1986) Toxicity of nitrite to fish: a review. Trans Am Fish Soc 115(2):183-195. https://doi. org/10.1577/1548-8659(1986) 115\%3c183:TONTF\% 3e2.0.CO;2

Mammoliti C (2004) Recovery plan for the Topeka shiner (Notropis topeka) in Kansas. Kansas Department of 
Wildlife and Parks, Pratt. https://www.ksoutdoors.com/ content/download/7244/36042/file/Topeka\%20shiner.pdf

Matthews WJ, Maness JD (1979) Critical thermal maxima, oxygen tolerances and success of cyprinid fishes in a southwestern river. Am Midl Nat 102(2):374-377. https:// doi.org/10.2307/2424665

McKenzie DJ, Garofalo E, Winter MJ, Ceradini S, Verweij F, Day N, Hayes R, van der Oost R, Butler PJ, Chipman JK, Taylor EW (2007) Complex physiological traits as biomarkers of the sub-lethal toxicological effects of pollutant exposure in fishes. Philos Trans R Soc Lond, B 362(1487):2043-2059. https://doi.org/10.1098/rstb.2007.2100

McPhee DL, Janz DM (2014) Dietary selenomethionine exposure alters swimming performance, metabolic capacity and energy homeostasis in juvenile fathead minnow. Aquat Toxicol 155:91-100. https://doi.org/10.1016/j.aquat ox.2014.06.012

Meador MR, Frey WF (2018) Relative importance of waterquality stressors in predicting fish community responses in midwestern streams. J Am Water Resour Assoc 54(3):708-723. https://doi.org/10.1111/1752-1688.12646

Meeuwig MH, Dunham JB, Hayes JP, Vinyard GL (2004) Effects of constant and cyclical thermal regimes on growth and feeding of juvenile cutthroat trout of variable sizes. Ecol Freshw Fish 13(3):208-216. https://doi.org/10. 1111/j.1600-0633.2004.00052.x

Missouri Department of Conservation (MDC) (2010) A tenyear strategic plan for the recovery of the Topeka Shiner in Missouri: July 1, 2010 - June 30, 2020. Missouri Department of Conservation, Jefferson City, MO, USA.

Missouri Department of Natural Resources (MDNR) (2014) Rules of Department of Natural Resources Division 20 - Clean Water Commission Chapter 7 - Water Quality. Missouri Department of Natural Resources, Jefferson City, MO, USA.

Mount DI (1973) Chronic effect of low pH on fathead minnow survival, growth and reproduction. Water Res 7(7):987993. https://doi.org/10.1016/0043-1354(73)90180-2

Mundahl ND (1990) Heat death of fish in shrinking stream pools. Am Midl Nat 123(1):40-46. https://doi.org/10. 2307/2425758

Neuswanger JR, Wipfli MS, Rosenberger AE, Hughes NF (2016) Measuring fish and their physical habitats: versatile 2D and 3D video techniques with user-friendly software. Can J Fish Aquat Sci 73(12):1861-1873. https://doi. org/10.1139/cjfas-2016-0010

Ostrand KG, Wilde GR (2001) Temperature, dissolved oxygen, and salinity tolerances of five prairie stream fishes and their role in explaining fish assemblage patterns. Trans Am Fish Soc 130(5):742-749. https://doi.org/10.1577/ 1548-8659(2001)130\%3c0742:TDOAST\%3e2.0.CO;2

Overturf K, Casten MT, LaPatra SL, Rexroad C III, Hardy RW (2003) Comparison of growth performance, immunological response and genetic diversity of five strains of rainbow trout (Oncorhynchus mykiss). Aquaculture 217(1-4):93106. https://doi.org/10.1016/S0044-8486(02)00014-5

Pflieger, WL (1997) The fishes of Missouri: Missouri Department of Conservation, Jefferson City.

Plaut I (2001) Critical swimming speed: its ecological relevance. Comp Biochem Physiol a: Mol Integr Physiol 131(1):41-50. https://doi.org/10.1016/S1095-6433(01)00462-7
Podrabsky JE, Somero GN (2004) Changes in gene expression associated with acclimation to constant temperatures and fluctuating daily temperatures in an annual killifish Austrofundulus limnaeus. J Exp Biol 207(13):2237-2254. https://doi.org/10.1242/jeb.01016

Poole GC, Dunham JB, Keenan DM, Sauter ST, McCullough DA, Mebane C, Lockwood JC, Essig DA, Hicks MP, Sturdevant DJ, Materna EJ, Spalding SA, Risley J, Deppman M (2004) The case for regime-based water quality standards. Bioscience 54(2):155-161. https://doi.org/10.1641/ 0006-3568(2004)054[0155:TCFRWQ]2.0.CO;2

Team, R. Core (2015) A language and environment for statistical computing [Internet]. Vienna, Austria

Richter BD, Braun DP, Mendelson MA, Master LL (1997) Threats to imperiled freshwater fauna: amenazas a la fauna dulceacuicola en riesgo. Conserv Biol 11(5):10811093. https://doi.org/10.1046/j.1523-1739.1997.96236.x

Shearer J et al (2003) Topeka Shiner (Notropis topeka) Management Plan for the State of South Dakota. South Dakota Department of Game, Fish and Parks, Pierre South Dakota. https://puc.sd.gov/commission/dockets/Hydrocarbo nPipeline/2014/HP14-002/rstexhibit/16.pdf

Smale MA, Rabeni CF (1995) Hypoxia and hyperthermia tolerances of headwater stream fishes. Trans Am Fish Soc 124(5):698-710. https://doi.org/10.1577/1548-8659(1995) 124\%3c0698:HAHTOH\%3e2.3.CO;2

Small K, Keller Kopf R, Watts RJ, Howitt J (2014) Hypoxia, blackwater and fish kills: experimental lethal oxygen thresholds in juvenile predatory lowland river fishes. PLoS ONE 9(4):e94524. https://doi.org/10.1371/journal. pone.0094524

Speers-Roesch B, Norin T (2016) Ecological significance of thermal tolerance and performance in fishes: new insights from integrating field and laboratory approaches. Funct Eco 30(6):842-844. https://doi.org/10.1111/1365-2435. 12652

Tabor VM (1998) Final rule to list the Topeka shiner as endangered. Fed Regis 63(240):69008-69021

Timmerman CM, Chapman LJ (2004) Hypoxia and interdemic variation in Poecilia latipinna. J Fish Biol 65(3):635-650. https://doi.org/10.1111/j.0022-1112.2004.00474.x

Venables WN, Ripley BD (2002) Modern Applied Statistics with S, 4th edn. Springer, New York

Wall SS, Berry CR Jr, Blausey CM, Jenks JA, Kopplin CJ (2004) Fish habitat modeling for gap analysis to conserve the endangered Topeka shiner (Notropis topeka). Can J Fish Aquat Sci 61(6):954-973. https://doi.org/10.1139/ f04-017

Ward DL, Maughan OE, Bonar SA (2002) A variable-speed swim tunnel for testing the swimming ability of age-0 fish. N Am J Aquac 64(3):228-231. https://doi.org/10.1577/ 1548-8454(2002)064\%3c0228:AVSSTF\%3e2.0.CO;2

Wickham H (2009) Elegant graphics for data analysis (ggplot2). Spring International Publishing

Publisher's note Springer Nature remains neutral with regard to jurisdictional claims in published maps and institutional affiliations. 